\title{
Allylferrocenylselenide and the synthesis of the first seleno-substituted allenylidene complex: synthesis, spectroscopy, electrochemistry and the effect of electron transfer from the ferrocenylselenyl subunit
}

\author{
Stephan Hartmann, Rainer F. Winter*, Thomas Scheiring, Matthias Wanner \\ Institut für Anorganische Chemie der Universität Stuttgart, Pfaffenwaldring 55, D-70569 Stuttgart, Germany
}

\begin{abstract}
Allylferrocenylselenide (2) is prepared from diferrocenyldiselenide (1Se) which was characterized along with its sulfur analog $1 \mathrm{~S}$ by X-ray structure analysis. In the crystal lattice the packing is determined by 'point-to-face' $\mathrm{CH}^{\cdots} \pi$ interactions with close contacts between the $\mathrm{CH} \pi$ donors and cyclopentadienyl rings as the $\pi$ acceptors. Compound 2 is then used in the trapping of the primary butatrienylidene intermediate trans $-\left[\mathrm{ClRu}(\mathrm{dppm})_{2}=\mathrm{C}=\mathrm{C}=\mathrm{C}=\mathrm{CH}_{2}\right]^{+}$. The isolated product, trans $-\left[\mathrm{Cl}(\mathrm{dppm})_{2} \mathrm{Ru}=\mathrm{C}=\mathrm{C}=\right.$ $\left.\mathrm{C}(\mathrm{SeFc})\left(\mathrm{C}_{4} \mathrm{H}_{7}\right)\right]^{+}(3)(\mathrm{Fc}=$ ferrocenyl), represents the first seleno-substituted allenylidene complex to be reported to date. Compound 3 is formed in a sequence involving regioselective addition of the selenium nucleophile to $\mathrm{C}_{\gamma}$ followed by hetero-Cope-rearrangement of the allyl vinyl substituted $\mathrm{SeR}_{3}^{+}$cation. Its spectroscopic properties place 3 at an intermediate position between sulfur and arene substituted all-carbon allenylidene complexes of the same metal fragment. The selenoallenylidene complex 3 contains a redox active ferrocenyl substituent attached to the heteroatom giving rise to reversible electrochemistry. ESR spectroscopy proves that electron transfer occurs from this site and its effect on the spectroscopic properties of 3 is probed by combining electrochemistry and IR or UV-vis/NIR spectroscopy by in situ techniques. In contrast, the reversible reduction primarily involves the allenylidene ligand as ascertained by ESR spectroscopy. In situ spectro-electrochemical techniques reveal how the reduction affects the bonding within the unsaturated ligand. (C) 2001 Elsevier Science B.V. All rights reserved.
\end{abstract}

\section{Introduction}

Established methods for the synthesis of heteroatom substituted allenylidene complexes include the aminolysis or alcoholysis of alkynyl substituted alkoxy- or aminocarbene complexes [1-3], sometimes in the presence of a Lewis acid [4], and the regioselective addition of protic nucleophiles to cumulenylidene complexes with more extended unsaturated carbon chains as terminally bonded ligands. Examples are butatrienylidene [5-8] or pentatetraenylidene species [9-13]. A related procedure studied in our laboratory employs the reac-

\footnotetext{
* Corresponding author. Tel: + 49-711-685-4097; fax: + 49-711685-4165.

E-mail address: winter@iac.uni-stuttgart.de (R.F. Winter).
}

tive butatrienylidene intermediate trans $-\left[\mathrm{Cl}\left(\mathrm{L}_{2}\right)_{2} \mathrm{Ru}=\right.$ $\left.\mathrm{C}=\mathrm{C}=\mathrm{C}=\mathrm{CH}_{2}\right]^{+}\left(\mathrm{L}_{2}=\right.$ chelating diphosphine $)$ and allyl substituted aprotic nucleophiles as trapping agents. Regioselective addition of the nucleophile to $\mathrm{C}_{\gamma}$ forms adducts with a cationic allyl vinyl substituted heteroatomic moiety. These subsequently rearrange to the isomeric heteroatom substituted allenylidene congeners by a Cope-type process occurring under remarkably mild conditions [14-16] (Scheme 1). Both these methods also allowed us, for the first time, to prepare sulfur substituted allenylidene complexes [15]. We have also reported on a reaction of the above butatrienylidene intermediate with ( $N, N$-dimethylaminomethyl)ferrocene, where the resonance stabilized ferrocenylmethylene carbenium ion, $\mathrm{FcCH}_{2}^{+}$, acts as a proton equivalent, giving rise to the ferrocenylethyl substituted aminoallenylidene complex trans $-\left[\mathrm{Cl}(\mathrm{dppm})_{2} \mathrm{Ru}=\right.$ 
$\left.\mathrm{C}=\mathrm{C}=\mathrm{C}\left(\mathrm{NMe}_{2}\right) \mathrm{C}_{2} \mathrm{H}_{4} \mathrm{Fc}\right]^{+} \quad\left(\mathrm{Fc}=\left(\eta^{5}-\mathrm{C}_{5} \mathrm{H}_{4} \mathrm{Fe}\left(\eta^{5} \mathrm{C}_{5} \mathrm{H}_{5}\right)\right)\right.$, dppm $=\mathrm{Ph}_{2} \mathrm{PCH}_{2} \mathrm{PPh}_{2}$ ) by migration to the neighboring $\mathrm{C}_{\delta}$ [8]. This compound features a well behaved redox active ferrocenyl substituent incorporated into the aliphatic side chain of the cumulated ligand.

In heteroatom substituted allenylidene complexes a naked cumulated $\mathrm{C}_{3}$ ligand bridges a potentially redox active transition metal moiety and a heteroatomic substituent while, like other highly unsaturated all-carbon chains [17-26], providing an efficient pathway for electronic communication between them $[27,28]$. The properties of such systems should therefore depend on the nature of both the heteroatom and the metal fragment. This thought motivated us to further extend the range of heteroatomic substituents attached to the allenylidene ligand. If either the metal or the substituents on the $\mathrm{C}$-heteroatom terminus of the allenylidene ligand are themselves electroactive, this provides us with the opportunity to study how the electronic modifications induced by electron transfer affect their properties and the bonding within the $\mathrm{RuC}_{3} \mathrm{ER}_{n}$-entity. Allenylidene complexes are especially well suited for such studies since they feature highly intense UV-vis and IR chromophores and possibly EPR active nuclei that allow to probe for these effects. Previous studies on trans$\left[\mathrm{Cl}(\mathrm{dppm})_{2} \mathrm{Ru}=\mathrm{C}=\mathrm{C}=\mathrm{C}\left(\mathrm{NMe}_{2}\right) \mathrm{C}_{2} \mathrm{H}_{4} \mathrm{Fc}\right]^{+}$have given the following results: stepwise oxidation of first the ferrocenyl moiety and then the ruthenium(II) center gave rise to a small red-shift of the UV-vis charge transfer band in the visible range and the CC-stretch in the infrared spectrum and then a larger shift of both these bands to higher energies as the ruthenium is oxidized [8]. The spectroscopic changes accompanying ferrocene oxidation were, however, rather small owing to the ethylene insulator connecting the $\mathrm{RuC}_{3}$ chromophore

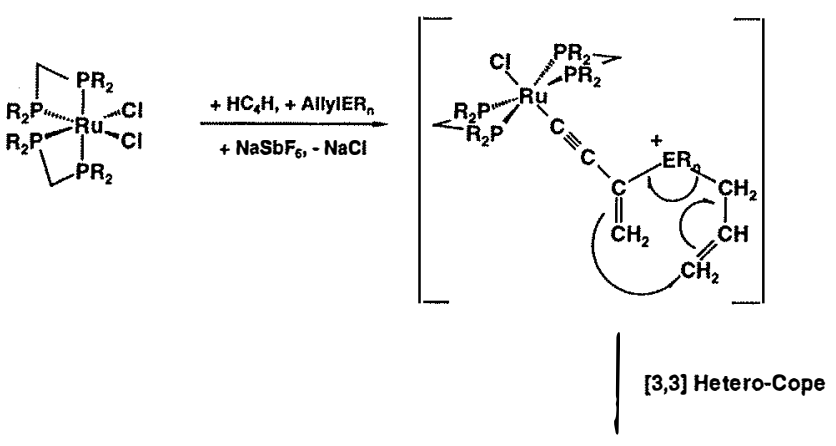

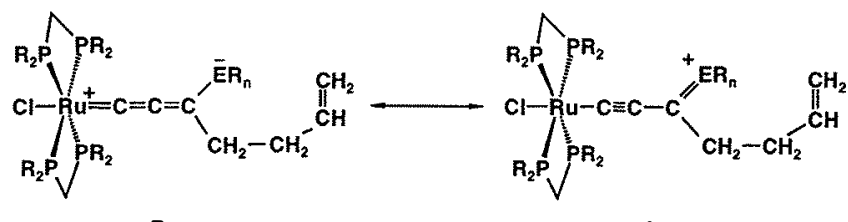
B and the ferrocenyl substituent. Therefore allenylidene complexes with the additional redox active tag in close proximity to the allenylidene ligand were sought as superior test cases. One conceivable way to access such systems is to employ heteroatomic substituents that are also electroactive. In this respect ferrocene derived systems are ideal candidates since they combine highly reversible electrochemistry and the easy introduction of various heteroatomic functionalities. In the present study we describe our progress along both these lines, i.e. adding selenium to the list of heteroatoms covalently attached to the $\mathrm{RuC}_{3}$ cumulenylidene chain combined with additional electroactivity due to the ferrocenyl moiety directly bonded to selenium.

\section{Results and discussion}

\subsection{Synthesis of allylferrocenylselenide (2) and structural characterization of diferrocenyldiselenide $(\mathbf{I S e})$ and diferrocenyldisulfide $(\mathbf{I S})$}

Allylferrocenylselenide (2) was identified as an ideal trapping reagent for the primary ruthenium butatrienylidene intermediate trans $-\left[\mathrm{Cl}(\mathrm{dppm})_{2} \mathrm{Ru}=\mathrm{C}=\right.$ $\left.\mathrm{C}=\mathrm{C}=\mathrm{CH}_{2}\right]^{+}$. This allowed us to achieve simultaneously the two objectives outlined above. The unsymmetric selenoether was prepared with reference to the procedures by Herberhold [29,30] and Uemura [31,32] via diferrocenyldiselenide (1Se) as the isolated intermediate. Subsequent $\mathrm{BEt}_{3} \mathrm{H}^{-}$reduction of the $\mathrm{Se}-\mathrm{Se}$ bond followed by treatment with allyliodide afforded allylferrocenylselenide in excellent yield. Diferrocenyldiselenide itself has been reported on various occasions. Its structure, however, has not been established to date although some amino-substituted derivatives have been structurally characterized [31-34]. In a related line of research we also synthesized diferrocenyldisulfide (1S). Its structure has also not been determined and only that of the related 1,1"-bis(1,2-dithia(2)ferrocenophane) has been reported [35]. We were able to obtain single crystals of both these compounds as orange blocks (1S) or orange plates (1Se) from $\mathrm{CH}_{2} \mathrm{Cl}_{2} /$ hexanes suitable for X-ray structure analysis. Fig. 1 depicts a view of a molecule of 1Se along with the atomic numbering. Pertinent bond parameters of $1 \mathrm{~S}$ and $1 \mathrm{Se}$ are collected in Table 1 while crystal data and refinement details are provided in Table 2 . Both crystallize in the chiral space group $P 2_{1}$ and, in each case, the specimen chosen contains the right handed helical form with a CEEC $(E=S$, Se $)$ dihedral angle of $-88.7(4)^{\circ}(\mathbf{1 S e})$ or $-90.3(2)^{\circ}$ (1S). Other diferrocenyldiselenides or disulfidses display similar values in the range of 84.9$94.3^{\circ}$ (integers). The Se-Se bond of 2.3504(14) $\AA$ in 1 Se is slightly long with respect to diaryldiselenides but agrees well with that found in substituted diferrocenyl 


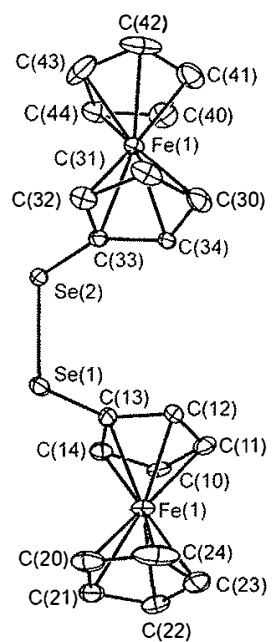

Fig. 1. Plot of a molecule of 1Se with atomic numbering scheme. Thermal ellipsoids are drawn at a $30 \%$ probability level. Hydrogen atoms are omitted for clarity.

Table 1

Bond lengths $(\AA)$ and bond angles $\left(^{\circ}\right)$ for $1 \mathrm{~S}$ and 1 Se

\begin{tabular}{|c|c|c|c|}
\hline \multicolumn{2}{|l|}{ 1S } & \multicolumn{2}{|l|}{ 1Se } \\
\hline \multicolumn{4}{|l|}{ Bond lengths } \\
\hline$S(1)-S(2)$ & $2.0783(12)$ & $\operatorname{Se}(1)-\operatorname{Se}(2)$ & $2.3504(14)$ \\
\hline $\mathrm{Fe}(1)-\mathrm{C}(10)$ & $2.029(4)$ & $\mathrm{Fe}(1)-\mathrm{C}(10)$ & $2.029(11)$ \\
\hline $\mathrm{Fe}(1)-\mathrm{C}(11)$ & $2.039(3)$ & $\mathrm{Fe}(1)-\mathrm{C}(11)$ & $2.057(12)$ \\
\hline $\mathrm{Fe}(1)-\mathrm{C}(12)$ & $2.050(4)$ & $\mathrm{Fe}(1)-\mathrm{C}(12)$ & $2.055(9)$ \\
\hline $\mathrm{Fe}(1)-\mathrm{C}(13)$ & $2.050(5)$ & $\mathrm{Fe}(1)-\mathrm{C}(13)$ & $2.038(10)$ \\
\hline $\mathrm{Fe}(1)-\mathrm{C}(14)$ & $2.042(4)$ & $\mathrm{Fe}(1)-\mathrm{C}(14)$ & $2.057(12)$ \\
\hline $\mathrm{Fe}(1)-\mathrm{C}(20)$ & $2.042(5)$ & $\mathrm{Fe}(1)-\mathrm{C}(20)$ & $2.049(13)$ \\
\hline $\mathrm{Fe}(1)-\mathrm{C}(21)$ & $2.039(5)$ & $\mathrm{Fe}(1)-\mathrm{C}(21)$ & $2.060(12)$ \\
\hline $\mathrm{Fe}(1)-\mathrm{C}(22)$ & $2.037(5)$ & $\mathrm{Fe}(1)-\mathrm{C}(22)$ & $2.031(11)$ \\
\hline $\mathrm{Fe}(1)-\mathrm{C}(23)$ & $2.046(4)$ & $\mathrm{Fe}(1)-\mathrm{C}(23)$ & $2.046(13)$ \\
\hline $\mathrm{Fe}(1)-\mathrm{C}(24)$ & $2.050(4)$ & $\mathrm{Fe}(1)-\mathrm{C}(24)$ & $2.023(13)$ \\
\hline $\mathrm{Fe}(2)-\mathrm{C}(30)$ & $2.033(3)$ & $\mathrm{Fe}(2)-\mathrm{C}(30)$ & $2.050(12)$ \\
\hline $\mathrm{Fe}(2)-\mathrm{C}(31)$ & $2.051(4)$ & $\mathrm{Fe}(2)-\mathrm{C}(31)$ & $2.054(10)$ \\
\hline $\mathrm{Fe}(2)-\mathrm{C}(32)$ & $2.056(4)$ & $\mathrm{Fe}(2)-\mathrm{C}(32)$ & $2.060(10)$ \\
\hline $\mathrm{Fe}(2)-\mathrm{C}(33)$ & $2.055(4)$ & $\mathrm{Fe}(2)-\mathrm{C}(33)$ & $2.023(9)$ \\
\hline $\mathrm{Fe}(2)-\mathrm{C}(34)$ & $2.043(4)$ & $\mathrm{Fe}(2)-\mathrm{C}(34)$ & $2.034(10)$ \\
\hline $\mathrm{Fe}(2)-\mathrm{C}(40)$ & $2.040(5)$ & $\mathrm{Fe}(2)-\mathrm{C}(40)$ & $2.036(14)$ \\
\hline $\mathrm{Fe}(2)-\mathrm{C}(41)$ & $2.038(5)$ & $\mathrm{Fe}(2)-\mathrm{C}(41)$ & $2.029(12)$ \\
\hline $\mathrm{Fe}(2)-\mathrm{C}(42)$ & $2.036(4)$ & $\mathrm{Fe}(2)-\mathrm{C}(42)$ & $2.012(12)$ \\
\hline $\mathrm{Fe}(2)-\mathrm{C}(43)$ & $2.022(4)$ & $\mathrm{Fe}(2)-\mathrm{C}(43)$ & $2.025(14)$ \\
\hline $\mathrm{Fe}(2)-\mathrm{C}(44)$ & $2.034(5)$ & $\mathrm{Fe}(2)-\mathrm{C}(44)$ & $2.049(12)$ \\
\hline $\mathrm{S}(1)-\mathrm{C}(10)$ & $1.762(4)$ & $\mathrm{Se}(1)-\mathrm{C}(13)$ & $1.898(10)$ \\
\hline$S(2)-C(30)$ & $1.750(4)$ & $\mathrm{Se}(2)-\mathrm{C}(33)$ & $1.904(9)$ \\
\hline \multicolumn{4}{|l|}{ Bond angles } \\
\hline$C(10)-S(1)-S(2)$ & $103.29(13)$ & $C(13)-\operatorname{Se}(1)-\operatorname{Se}(2)$ & $101.0(3)$ \\
\hline$C(11) C(10)-S(1)$ & $125.7(3)$ & $\mathrm{C}(12)-\mathrm{C}(13)-\mathrm{Se}(1)$ & $124.6(7)$ \\
\hline$C(14)-C(10)-S(1)$ & $126.1(3)$ & $C(14)-C(13)-S e(1)$ & $126.6(7)$ \\
\hline$C(30)-S(2)-S(1)$ & $102.43(13)$ & $\mathrm{C}(33)-\mathrm{Se}(2)-\mathrm{Se}(1)$ & $99.9(3)$ \\
\hline$C(31)-C(30)-S(2)$ & $126.2(3)$ & $C(32)-C(33)-\operatorname{Se}(2)$ & $126.8(8)$ \\
\hline$C(34)-C(30)-S(2)$ & $125.7(3)$ & $C(34)-C(33)-\operatorname{Se}(2)$ & $124.9(8)$ \\
\hline
\end{tabular}

diselenides (2.347-2.362 $\AA$ ). The same holds for 1S which exhibits a S-S bond length of 2.0783(12) A, slightly longer than that in the related ferrocenophane
$(2.066 \AA)$. The two cyclopentadienyl rings attached to the same iron are basically coplanar and display a staggered conformation with angles between the normals of the best planes of 1.1 and $3.3^{\circ}(\mathbf{S e})$ or 1.1 and $2.6^{\circ}(1 \mathrm{~S})$ and average rotational angles of $6.7(\mathrm{Fe} 1)$ and $1.6^{\circ}(\mathrm{Fe} 2)$ for $\mathbf{1 S e}$ and 11.4 and $8.2^{\circ}$ for $\mathbf{1 S}$. The two ferrocenyl subunits connected by the diselenide bridge are also almost coparallel as is evident from the angle between the normals to the substituted cyclopentadienyl rings of $5.0^{\circ}(\mathbf{1 S e})$ and $6.9^{\circ}(\mathbf{1 S})$. There is a tendency toward shorter $\mathrm{Fe}-\mathrm{C}$ bond distances for the substituted carbon atoms as compared to the other $\mathrm{Fe}-\mathrm{C}$ bonds within the same ring (e.g. 2.029 (4) $\AA$ for $\mathrm{Fe}(1)-\mathrm{C}(10)$ with $\mathrm{Fe}(1)-\mathrm{C}(11)$ to $\mathrm{Fe}(1)-\mathrm{C}(14)$ bonds ranging from 2.039(3) to 2.050(5) $\AA$ ).

Both compounds exhibit quite an interesting packing motif in the solid state. Individual molecules are aligned to one-dimensional infinite chains that run parallel to each other. Within adjacent chains molecules are oriented almost orthogonally to their neighbors such that the normals to the best planes of their cyclopentadienyl rings form angles of 82.5 and $81.9^{\circ}$ (1Se) or 82.4 and $81.7^{\circ}(\mathbf{1 S})$. Each cyclopentadienyl (Cp) ring engages in $\mathrm{CH}^{\cdots} \pi$ stacking interactions with those of its immediate neighbor, serving simultaneously as a $\mathrm{CH} \cdots \pi$ donor to one and an arene $\pi$ acceptor to another $\mathrm{Cp}$-ring. The resulting packing motif is illustrated in Fig. 2 for diferrocenyldisulfide (1S). The $\mathrm{CH}^{\cdots} \pi \pi$ interactions present in $1 \mathrm{~S}$ and 1Se can be classified as belonging to the point-to-face or T-shape type [36] representing a motif that is encountered frequently in simple aromatic hydrocarbons like benzene itself [37-41]. The bond vectors of the individual $\mathrm{CH}$ donors (one $\mathrm{CH}$ bond per $\mathrm{Cp}$ ring) are roughly orthogonal to the arene plane of the corresponding $\pi$ acceptor as is evident from the angles formed between them and the normals to the best planes of the neighboring Cp-rings of $10.2-20.4^{\circ}$ in 1Se and $12.9-46.5^{\circ}$ in 1S. For 1S the protons of the $\pi$ interacting $\mathrm{CH}$-entities are located 2.623 ( $\mathrm{H} 40$ to C30A-C34A), 2.754 (H13B to C20A-C24A), 2.808 (H32A to $\mathrm{C} 10-\mathrm{C} 14)$ and $2.817 \AA$ (H21A to C40-C44) away from the best planes through the ring atoms indicated. Equivalent distances of 1 Se are somewhat longer at 2.770 ( $\mathrm{H} 10 \mathrm{~B}$ to $\mathrm{C} 20 \mathrm{~A}-\mathrm{C} 24 \mathrm{~A}), 2.839(\mathrm{H} 31 \mathrm{~A}$ to $\mathrm{C} 10-\mathrm{C} 14), 2.855$ (H24A to $\mathrm{C} 40-\mathrm{C} 44)$ and $3.109 \AA$ ( $\mathrm{H} 40$ to $\mathrm{C} 30 \mathrm{~A}-\mathrm{C} 34 \mathrm{~A})$ due to the larger dimensions of the selenium compound. These values compare well to the distance of $2.764 \AA$ in benzene itself [38] and the majority of such interactions. Thus, a recent CSD search gave an average value of 2.76(10) $\AA$ [42]. The closest contact in $1 \mathrm{~S}$ is, however, remarkably short [43] and even resembles $\mathrm{CH} \cdots \pi$ interactions between much stronger alkyne $\mathrm{CH}$ donors and arenes $[44,45]$. 


\subsection{The selenoallenylidene complex trans-}

$\left[\mathrm{Cl}(\mathrm{dppm})_{2} \mathrm{Ru}=\mathrm{C}=\mathrm{C}=\mathrm{C}(\mathrm{SeFc}) \mathrm{C}_{2} \mathrm{H}_{4} \mathrm{CH}=\mathrm{CH}_{2}\right]^{+}$

For the preparation of the target selenoallenylidene complex, allylferrocenylselenide (three equivalents) was added as a trapping agent to the blue-green suspension formed from cis- $\mathrm{RuCl}_{2}(\mathrm{dppm})_{2}, \mathrm{NaSbF}_{6}$ and excess butadiyne which induced a gradual color change to intense orange brown. IR monitoring reveals the formation of a strong RuCC band at $1940 \mathrm{~cm}^{-1}$ at the expense of an absorption at $1898 \mathrm{~cm}^{-1}$ that we ascribe to the reactive butatrienylidene intermediate supposedly formed under these conditions. The IR absorption is at the very same position as in thioallenylidene complexes already reported by us [15]. The pure product was obtained after washing of the crude residue and repeated reprecipitation from dichloromethane/hexanes.

Table 2

Crystal data and structure refinement for $1 \mathrm{~S}$ and 1Se

\begin{tabular}{|c|c|c|}
\hline & $1 \mathrm{~S}$ & 1Se \\
\hline Empirical formula & $\mathrm{C}_{20} \mathrm{H}_{18} \mathrm{Fe}_{2} \mathrm{~S}_{2}$ & $\mathrm{C}_{20} \mathrm{H}_{18} \mathrm{Fe}_{2} \mathrm{Se}_{2}$ \\
\hline Formula weight & 434.16 & 527.96 \\
\hline Temperature $(\mathrm{K})$ & 173(2) & $173(2)$ \\
\hline Wavelength $(\bar{A})$ & 0.71073 & 0.71073 \\
\hline Crystal system & Monoclinic & Monoclinic \\
\hline Space group & $P 2_{1}$ & $P 2_{1}$ \\
\hline \multicolumn{3}{|l|}{ Unit cell dimensions } \\
\hline$a(\AA)$ & $6.1437(5)$ & $6.286(2)$ \\
\hline$b(\AA ̊)$ & $10.2520(8)$ & $10.330(3)$ \\
\hline$c(\AA)$ & $13.8667(10)$ & $14.082(3)$ \\
\hline$\beta\left(^{\circ}\right)$ & $94.290(5)$ & $94.78(2)$ \\
\hline$V\left(\AA^{3}\right)$ & $870.95(12)$ & $911.2(4)$ \\
\hline$Z$ & 2 & 2 \\
\hline$D_{\text {calc }}\left(\mathrm{Mg} \mathrm{m}^{-3}\right)$ & 1.656 & 1.924 \\
\hline $\begin{array}{l}\text { Absorption coefficient } \\
\left(\mathrm{mm}^{-1}\right)\end{array}$ & 1.903 & 5.584 \\
\hline$F(000)$ & 444 & 516 \\
\hline Crystal size $\left(\mathrm{mm}^{3}\right)$ & $0.4 \times 0.4 \times 0.1$ & $0.4 \times 0.1 \times 0.1$ \\
\hline$\theta$ Range $\left({ }^{\circ}\right)$ & $2.47-30.00$ & $2.45-30.00$ \\
\hline Limiting indices & $\begin{array}{l}-1 \leq h \leq 8 \\
-1 \leq k \leq 14 \\
-19 \leq l \leq 19\end{array}$ & $\begin{array}{l}-4 \leq h \leq 8 \\
-14 \leq k \leq 14 \\
-19 \leq l \leq 19\end{array}$ \\
\hline Reflections collected & 3664 & 3684 \\
\hline Independent reflections & $\begin{array}{l}2932 \\
\left.\left[R_{\mathrm{int}}=0.0406\right)\right]\end{array}$ & $3048\left[R_{\mathrm{imt}}=0.1189\right]$ \\
\hline Refinement method & $\begin{array}{l}\text { Full-matrix } \\
\text { least-squares on } \\
F^{2}\end{array}$ & $\begin{array}{l}\text { Full-matrix } \\
\text { least-squares on } \\
F^{2}\end{array}$ \\
\hline $\begin{array}{l}\text { Data/restraints/ } \\
\text { parameters }\end{array}$ & $2932 / 1 / 217$ & $3044 / 1 / 217$ \\
\hline Goodness-of-fit on $F^{2}$ & 1.069 & 1.058 \\
\hline $\begin{array}{l}\text { Final } R \text { indices } \\
\qquad[I>2 \sigma(I)]\end{array}$ & $\begin{array}{l}R_{1}=0.0422 \\
w R_{2}=0.1021\end{array}$ & $\begin{array}{l}R_{1}=0.0572 \\
w R_{2}=0.1465\end{array}$ \\
\hline$R$ indices (all data) & $\begin{array}{l}R_{1}=0.0471 \\
w R_{2}=0.1058\end{array}$ & $\begin{array}{l}R_{1}=0.0736 \\
w R_{2}=0.1662\end{array}$ \\
\hline $\begin{array}{l}\text { Absolute structure } \\
\text { parameter }\end{array}$ & $0.00(2)$ & $-0.03(3)$ \\
\hline $\begin{array}{l}\text { Largest difference peak } \\
\text { and hole }\left(\mathrm{e} \AA^{-3}\right)\end{array}$ & 1.004 and -1.203 & 1.277 and -1.563 \\
\hline
\end{tabular}

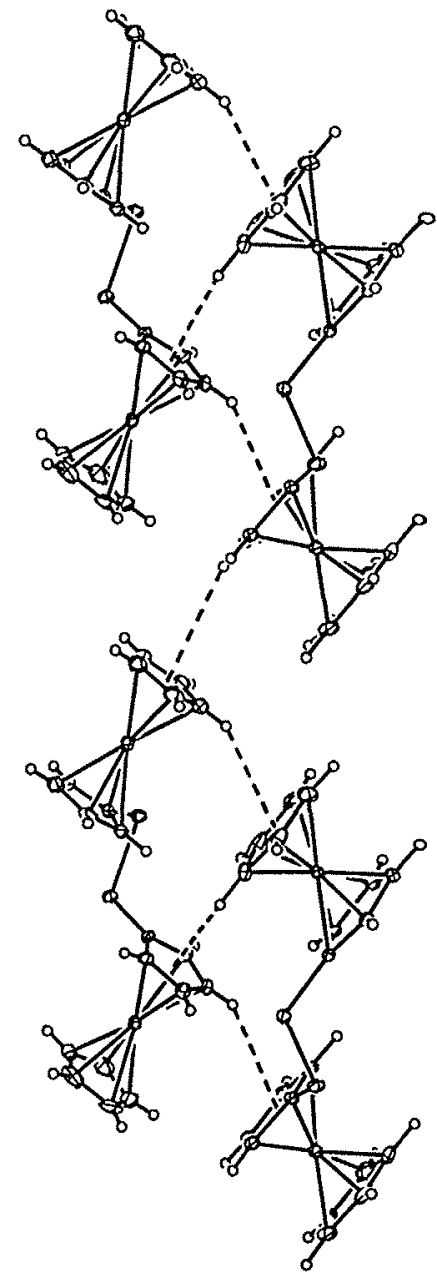

Fig. 2. Representation of the packing motif for $1 \mathrm{~S}$ and 1 Se as exemplified for $1 \mathrm{~S}$. The $\mathrm{CH}^{\cdots} \cdots \pi$ bonds are indicated by dotted lines from the $\mathrm{CH}$ donors to the center of the $\mathrm{Cp}$ rings.

Other purification methods such as recrystallization or column chromatography led to partial decomposition and are not advised. The dark brown solid thus obtained was readily identified as the target compound trans $-\left[\mathrm{Cl}(\mathrm{dppm})_{2} \mathrm{Ru}=\mathrm{C}=\mathrm{C}=\mathrm{C}(\mathrm{SeFc}) \mathrm{C}_{2} \mathrm{H}_{4} \mathrm{CH}=\mathrm{CH}_{2}\right]^{+}$(3) on the basis of its spectroscopic data. While solutions in chlorinated hydrocarbons are stable for long periods 3 instantaneously decomposes in stronger coordinating solvents like DMF. We note that seleno-substituted carbene complexes have been known for a long time $[46,47]$ while a cumulogous vinylidene derivative is only of very recent vintage [48].

The formation of 3 from allylferrocenylselenide and trans $-\left[\mathrm{Cl}(\mathrm{dppm}){ }_{2} \mathrm{Ru}=\mathrm{C}=\mathrm{C}=\mathrm{C}=\mathrm{CH}_{2}\right]^{+}$is thought to proceed by the mechanism outlined in Scheme 1, where $\mathrm{RE}_{n}$ represents the ferrocenylselenyl group, FcSe: regioselective addition of the nucleophilic selenoether to $\mathrm{C}_{\gamma}$ initially forms a cationic trisubstituted selenium center to which an allyl and a vinyl group are attached. Like its nitrogen or sulfur counterparts, this primary 
adduct is unstable and undergoes Cope (or Claisen)type [3,3] sigmatropic rearrangement to the final product. For allylic amines primary adducts trans$\left[\mathrm{Cl}(\mathrm{dppm})_{2} \mathrm{Ru}-\mathrm{C}=\mathrm{C}-\mathrm{C}\left(\mathrm{NR}_{2} \mathrm{R}^{\prime}\right)=\mathrm{CH}_{2}\right]^{+}$can be detected at early stages of the reaction by virtue of their characteristic CC stretch at ca. $2030 \mathrm{~cm}^{-1}$ in the IR. Stable 2-ammoniobutenynyl derivatives are obtained from such reactions for a variety of other amines and these exhibit an IR band at an identical position [49]. No such primary adduct is detected here which parallels our results in the sulfur case. This is in agreement with the inherently lower barrier to sigmatropic rearrangement for these heteroatoms as compared to the nitrogen substituted analogs [50,51].

In one of our previous accounts we have compared the spectroscopic and electrochemical data of heteroatom substituted ruthenium allenylidene complexes trans $-\left[\mathrm{Cl}(\mathrm{dppm})_{2} \mathrm{RuCCC}\left(\mathrm{ER}_{n}\right) \mathrm{R}^{\prime}\right]^{+}$where $\mathrm{ER}_{n}$ equals $\mathrm{NR}_{2}$, OR, SR and $\mathrm{Ph}[15]$. Within this series we noted a steady shift of the RuCC stretching frequency and the highly intense charge transfer band in the visible range to lower energies. This latter band originates from the symmetry allowed excitation from the second highest occupied level (HOMO-1) to the LUMO. It is observed at ca. $400 \mathrm{~nm}$ for amino-, $465 \mathrm{~nm}$ for thio- and $505 \mathrm{~nm}$ for all-carbon substituted allenylidene complexes bearing one or two arene substituents. The HOMO/LUMO transition itself is symmetry forbidden and gives rise to only a weak band at still lower energies $\left(\lambda_{\max }=710 \mathrm{~nm}\right.$ for 3, ca. $630 \mathrm{~nm}$ for amino-, $680 \mathrm{~nm}$ for thio- and ca. $800 \mathrm{~nm}$ for phenyl substituted allenylidene complexes). Other characteristic changes are the increasing low field field shift of the ${ }^{13} \mathrm{C}$ resonances of the cumulenic carbon atoms and an anodic displacement of both the oxidation and the reduction potentials which each pertain to a one-electron process. These observations were rationalized by an increasing contribution of the genuine cumulenic resonance form $\mathbf{B}$ with the positive charge on the metal as opposed to the alkynyl type resonance form $\mathbf{A}$ with the positive charge on the heteroatom as $\pi$ interactions between the unsaturated $\mathrm{C}_{3}$ ligand and the lone pair at the heteroatom become less efficient (see Scheme 1).

The present selenoallenylidene complex fits well into this series. Spectroscopic data place 3 between its sulfur and phenyl substituted all-carbon congeners. Thus, the ${ }^{13} \mathrm{C}$-NMR resonance signals of the cumulenic carbon atoms appear at $303.2\left(\mathrm{C}_{\alpha}\right), 180.8\left(\mathrm{C}_{\beta}\right)$ and $180.6\left(\mathrm{C}_{\gamma}\right)$ $\mathrm{ppm}$, the assignments being based on the PC coupling constants $\left(14.2 \mathrm{~Hz}\right.$ for the metal bound $\mathrm{C}_{\alpha}, 2.33 \mathrm{~Hz}$ for $\mathrm{C}_{\beta}$ and $1.89 \mathrm{~Hz}$ for $\mathrm{C}_{\gamma}$ ), which are generally expected to decrease with increasing distance from the metal for this class of compounds [52]. Selenium satellites for $\mathrm{C}_{\gamma}$ could not be detected with certainty due to the intrinsically low intensity of this signal and its further broadening by the small PC coupling. The ${ }^{13} \mathrm{C}$ values may be compared to the values for thio- $\left(\mathrm{C}_{\alpha}\right.$ ca. $285 \mathrm{ppm}, \mathrm{C}_{\beta}$, $\mathrm{C}_{\gamma}$ both ca. $170 \mathrm{ppm}$ ) and all-carbon substituted allenylidene complexes $\left(C_{\alpha}\right.$ ca. $310 \mathrm{ppm}, \mathrm{C}_{\beta}$ ca. $205 \mathrm{ppm}$, $\mathrm{C}_{\gamma}$ ca. $162 \mathrm{ppm}$ ). Other NMR spectroscopic data of interest include the ${ }^{1} \mathrm{H}$ - and ${ }^{13} \mathrm{C}-\mathrm{NMR}$ resonances of the ferrocenyl substituents at $\delta=70.07 \mathrm{ppm}$ for the unsubstituted and $\delta=69.31\left(\mathrm{C}^{1}\right), 75.21\left(\mathrm{C}^{2}, \mathrm{C}^{5}\right)$ and $72.12\left(\mathrm{C}^{3}, \mathrm{C}^{4}\right) \mathrm{ppm}$ for the substituted $\mathrm{Cp}$ ring. The proton resonance signals are significantly broadened and we attribute this to slow rotation around the CSe bond due to steric hindrance between the bulky coligands on the metal and the ferrocenyl substituent. Similar effects are well documented for thio- and seleno- substituted carbene complexes [47,53]. The ${ }^{77} \mathrm{Se}$ signal of 3 was observed at $\delta=797.7 \mathrm{ppm}$ as a singlet. While the RuCC stretch is at essentially the same position as in the sulfur analogs, the HOMO-1/LUMO and the HOMO/LUMO bands in the electronic spectra appear slightly red-shifted in the selenium derivative 3 $\left(\lambda_{\max }\right.$ at 487 and $\left.695 \mathrm{~nm}\right)$. This again places 3 at an aryl intermediate position between the sulfur and all carbon substituted congeners.

\subsection{Electrochemical investigation of $\mathbf{2}$ and $\mathbf{3}$}

The electrochemistry of diferrocenyldiselenide has already been scrutinized and the moderate splitting of the individual half-wave potentials of $140 \mathrm{mV}$ attributed to mainly electrostatic interactions between the two adjacent ferrocenyl subunits rather than electronic communication mediated by the diselenide bridge [54]. In $\mathrm{CH}_{2} \mathrm{Cl}_{2}$ solution allylferrocenylselenide 2 undergoes a fully reversible one-electron oxidation at $E_{1 / 2}=+0.055$ $\mathrm{V}$ versus the ferrocene/ferrocenium couple as ascertained by the usual diagnostic criteria such as the peak current ratio $i_{\mathrm{p}, \text { rev }} / i_{\mathrm{p} \text {. forw }}$ of essentially unity and peakto-peak separations and half peak widths identical to those of the internal decamethylferrocene calibrant. This first reversible process is followed by an irreversible multielectron wave at $+0.70 \mathrm{~V}$ which is accompanied by severe product adsorption onto the electrode surface. This wave can be attributed to the oxidation of the $\mathrm{C}-\mathrm{Se}$ bond.

In 3 , the ferrocenylselenyl subunit retains its reversible electrochemistry upon attachment to the allenylidene ligand. Substitution of the allyl group in $\mathbf{2}$ by the cationic $\left\{\mathrm{Cl}(\mathrm{dppm})_{2} \mathrm{RuC}_{3}\right\}^{+}$fragment in $\mathbf{3}$ shifts the half wave potential of this process anodically by 215 $\mathrm{mV}$ such that the oxidation is now observed at +0.27 $\mathrm{V}$ (peaks $\mathrm{B} / \mathrm{B}^{\prime}$ in Fig. 3). This is rather significant and can be taken as a further indication for the ability of the cumulated $\mathrm{C}_{3}$ ligand to transmit substituent effects between the bridged termini. Scanning into a more anodic range reveals two additional irreversible processes that partially overlap to a composite wave. We were not able to detect any of the associated return 
peaks even at temperatures as low as $195 \mathrm{~K}$. The more anodic of these features (peak D in Fig. 3) appears at a peak potential $\left(v=0.1 \mathrm{~V} \mathrm{~s}^{-1}\right)$ of $1.15 \mathrm{~V}$. It bears close resemblance to the second anodic process observed for allylferrocenylselenide $\mathbf{2}$ and it is therefore ascribed to the oxidation of the selenoether moiety. The other peak at $+0.93 \mathrm{~V}$ (peak C in Fig. 3) is characterized by a current similar to that of the reversible ferrocene-based one-electron process and is thus assigned to the primarily ruthenium centered oxidation of the selenoallenylidene complex. Oxidation processes in a similar potential range have been observed by us for related amino- $[8,16]$ and thio-substituted allenylidene complexes [15]. Scanning these irreversible waves generates the new cathodic features E and F (Fig. 3) which indicates degradation to other electroactive species. The position of peak $\mathrm{D}$ is still more anodic as the half wave potential for the reversible oxidation of thioallenylidene complexes $\left(E_{1 / 2} \mathrm{ca}\right.$. $\left.+0.86 \mathrm{~V}\right)$. One must, however, be aware that peak positions of irreversible waves are not strictly comparable to reversible half-wave potentials [55]. This may reflect the increasing acceptor properties of the ferrocenylselenyl moiety as the ferrocene subunit is oxidized. In addition, the selenoallenylidene complex 3 displays a fully reversible reduction at $E_{1 / 2}=-1.365$ $\mathrm{V}$ (wave $\mathrm{A} / \mathrm{A}^{\prime}$ in Fig. 3). This wave is at an identical position as those found for related sulfur substituted complexes $\left(E_{1 / 2}=-1.355\right.$ to $\left.-1.375 \mathrm{~V}\right)[15]$.

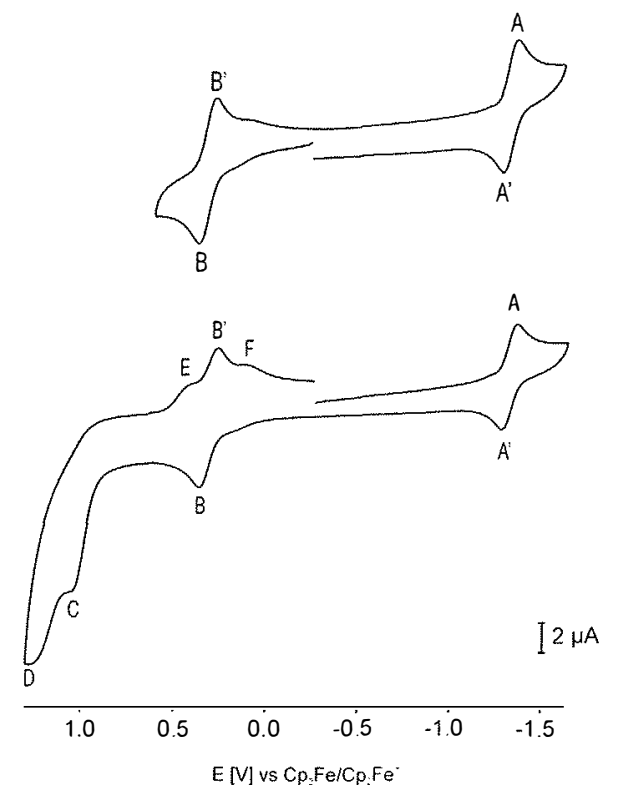

Fig. 3. Cyclic voltammogramms of 3 in $\mathrm{CH}_{2} \mathrm{Cl}_{2}$ at $0.1 \mathrm{~V} \mathrm{~s}^{-1}$ with (a) scan reversal after the first oxidation with initial anodic scan (upper trace) and (b) scan over the entire range, cathodic scan first (lower trace).

\subsection{Spectroelectrochemistry}

Combining electrochemistry with diverse spectroscopic methods may yield valuable information about the identity and localization of the primary redox sites within a more complex molecule and the changes in structure and bonding associated with electron transfer. Previous investigations on closely related thioallenylidene complexes have revealed that the reduction is primarily centered on the allenylidene ligand and produces a basically organic radical with resolved couplings to the protons of the methylene group attached to $C_{\gamma}$ and the four equivalent phosphorus nuclei on the metal [15]. The oxidation, on the other hand is a primarily metal based process and may be regarded as the $\mathrm{Ru}(\mathrm{II} / \mathrm{III})$ couple. In line with these results we have observed that the heteroatom influences the reduction potential in a much more profound way than the oxidation potential, whereas modifications at the metal site by substitution of the phosphine ligands have the opposite effect [16].

The selenoallenylidene complex $\mathbf{3}$ also adheres to this trend. In frozen solution ESR spectra of the reduced form exhibit a slightly broadened isotropic signal at $g_{\text {iso }}=2.0036$, a value typical of carbon centered radicals. In fluid solution, the signal evolves into a quintet of triplets with clearly resolved couplings to the protons of the methylene group attached to $\mathrm{C}_{\gamma}$ and the four phosphorus nuclei on ruthenium. Satellites due to coupling with the ${ }^{77} \mathrm{Se}$ isotope (relative abundance $7.6 \%$ ) are also discernible. The experimental and simulated spectra are compared in Fig. 4. Best agreement was obtained with $A\left({ }^{1} \mathrm{H}_{1} \mathrm{CH}_{2}\right)=10.15 \mathrm{G}, A\left({ }^{31} \mathrm{P}\right)=6.80 \mathrm{G}$ and $A\left({ }^{77} \mathrm{Se}\right)=41.5 \mathrm{G}$. The ESR pattern is thus best accomodated by the ruthenium alkynyl type resonance form where the unpaired electron resides on $\mathrm{C}_{\gamma}$ (Chart 1). As a consequence the $C_{\alpha} C_{\beta}$ bond should strengthen upon reduction and this is again supported by IR spectroelectrochemistry. In the reduced form the CC band has shifted from 1938 to 2044 wavenumbers, i.e. by more than $100 \mathrm{~cm}^{-1}$ to higher energies as compared to 3 (Fig. 5). This is accompanied by a severe loss of band intensity. Reoxidation reproduces the starting material in more than $90 \%$ optical yield such that this represents an intrinsic property of our system rather than the result of extensive decomposition. Similar effects have been noted before, either upon going from allenylidene to alkynyl [13] or from cationic to neutral allenylidene complexes $[15,56]$. The intensity loss can be traced back to the decreased dipole moment change associated with the CC stretch when the substituents become more similar in their charge or their electronic properties. In UV-vis spectroelectrochemistry the highly intense HOMO-1/LUMO transition as well as the less intense transitions at even lower energies bleach out and are replaced by a new band at 315 wavenum- 


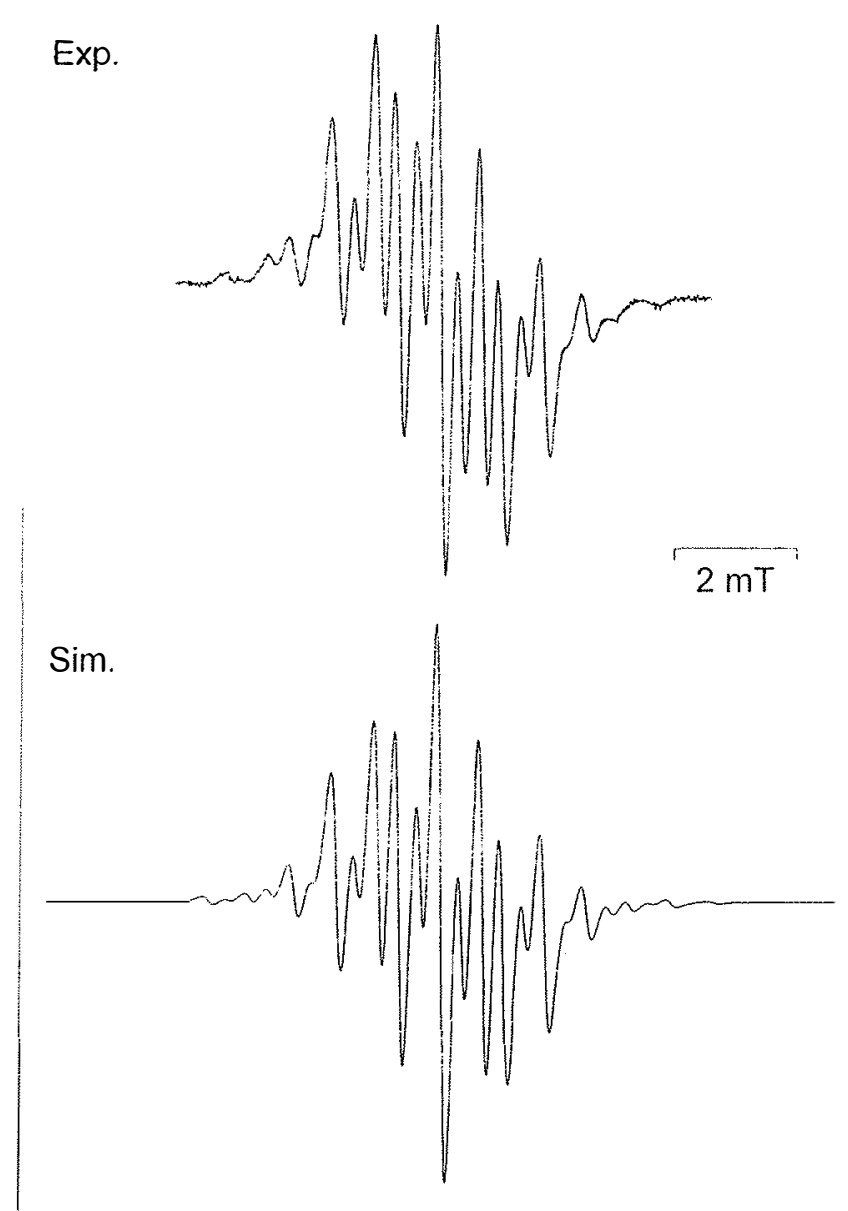

Fig. 4. Comparison of the experimental and the simulated ESR-spectrum of 3 after electrochemical reduction.

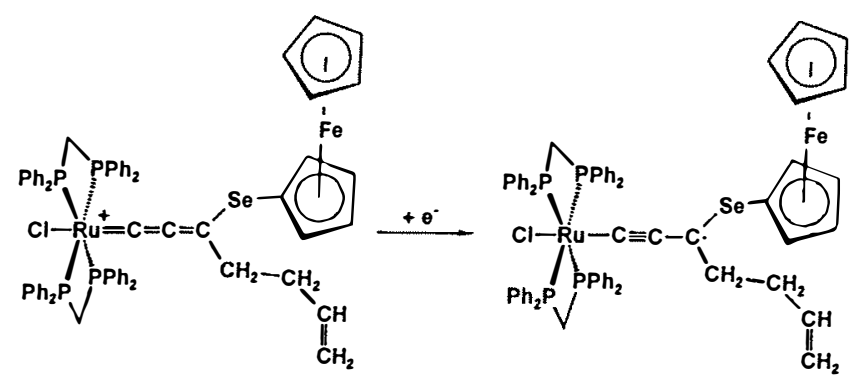

Chart 1.

bers, again in accord with a profound reorganization of the $\pi$-system and the diminuition of the conjugation length as the allenylidene chromophor turns into a predominantly acetylenic one.

Our investigations on trans $-\left[\mathrm{Cl}(\mathrm{dppm}){ }_{2} \mathrm{Ru}=\mathrm{C}=\right.$ $\left.\mathrm{C}=\mathrm{C}\left(\mathrm{NMe}_{2}\right) \mathrm{C}_{2} \mathrm{H}_{4} \mathrm{Fc}\right]^{+}(\mathrm{Fc}=$ ferrocenyl $)$ have produced first indications of the effect of the oxidation of an appended redox active moiety prior to the $\mathrm{Ru}(\mathrm{II} / \mathrm{III})$ process [8]. The spectral changes were, however, rather small due to the poorly conducting ethylene spacer separating the electroactive subunit from the allenyli- dene ligand. In trans $-\left[\mathrm{Cl}(\mathrm{dppm})_{2} \mathrm{Ru}=\mathrm{C}=\mathrm{C}=\mathrm{C}(\mathrm{Se}\right.$ $\left.\mathrm{Fc}) \mathrm{C}_{2} \mathrm{H}_{4} \mathrm{CH}=\mathrm{CH}_{2}\right]^{+}$(3) the secondary redox center is covalently linked to the heteroatom and is therefore much closer to the $\mathrm{RuC}_{3}$ chromophor. This should considerably enhance the effects of electron transfer from this site. Our spectroelectrochemical results on 3 bear witness to this notion. First it was probed by ESR spectroscopy that the first oxidation of $\mathbf{3}$ really involves the ferrocene site. While oxidized samples gave no signal at $77 \mathrm{~K}$, further cooling to $4 \mathrm{~K}$ produced a broad axial signal with a large g-anisotropy at $g_{\|}=4.332$ and $g_{\perp}=1.78(2)$ as is typical of substituted ferrocenium systems [57,58]. In IR spectroscopy the allenylidene band shifts to lower energy by about $10 \mathrm{~cm}^{-1}$ with concomittant intensity loss (Fig. 6). Again this is not a chemical problem but an intrinsic property since the optical yield of the rereduced species again exceeds $90 \%$. Both effects may be understood in line with the above reasoning: Oxidation of the ferrocene moiety renders the FcSe substituent a stronger acceptor putting

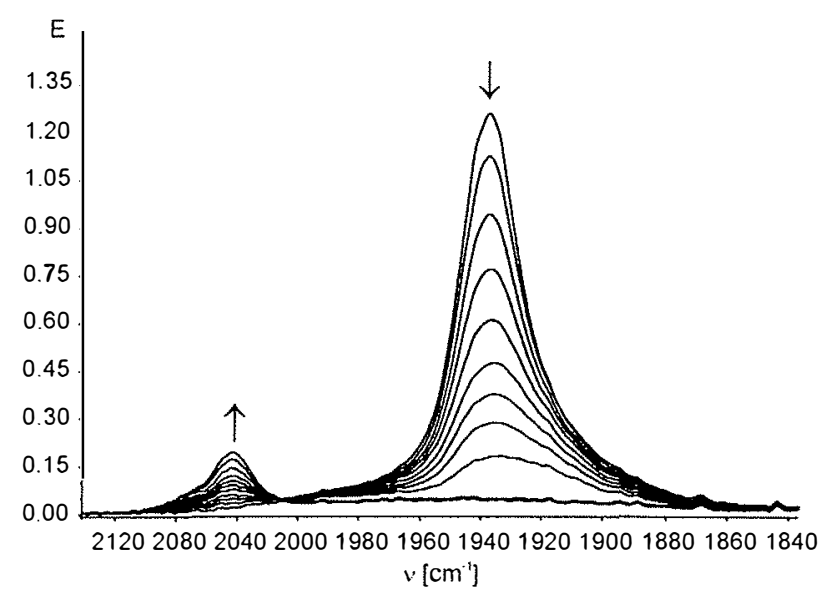

Fig. 5. IR-spectra obtained during electrochemical reduction of $\mathbf{3}$ in a thin layer cell.

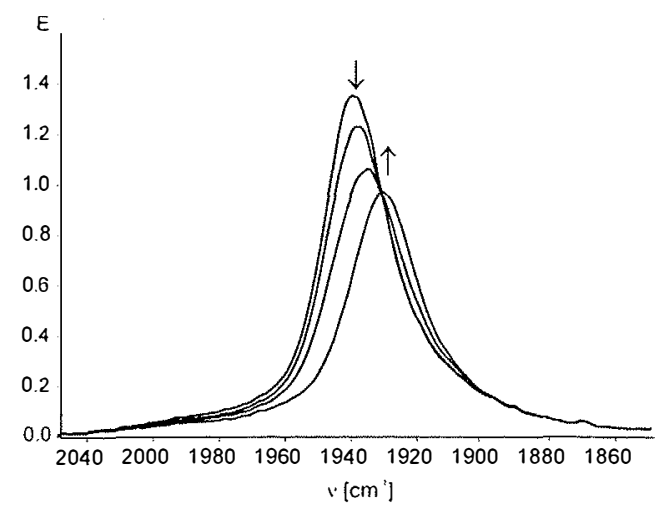

Fig. 6. IR-spectra obtained during electrochemical oxidation of $\mathbf{3}$ in a thin layer cell. 


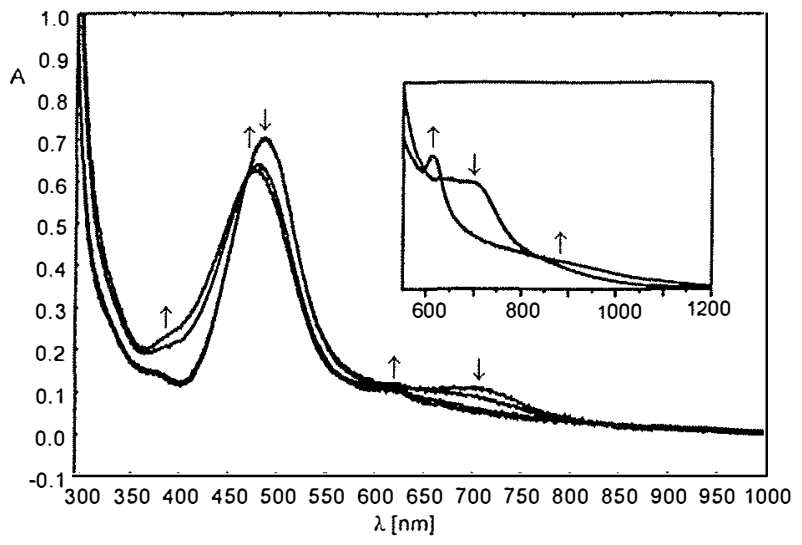

Fig. 7. UV-vis-spectra obtained during electrochemical oxidation of 3 in a thin layer cell.

Table 3

IR and UV-vis data in $1,2-\mathrm{C}_{2} \mathrm{H}_{4} \mathrm{Cl}_{2}$ solution for trans$\left[\mathrm{Cl}(\mathrm{dppm}){ }_{2} \mathrm{Ru}=\mathrm{C}=\mathrm{C}=\mathrm{C}(\mathrm{SeFc}) \mathrm{C}_{2} \mathrm{H}_{4} \mathrm{CH}=\mathrm{CH}_{2}\right]^{+}$(3) in different oxidation states

\begin{tabular}{|c|c|c|c|}
\hline & 3 & Oxidized form & Reduced form \\
\hline$v_{\mathrm{CC}}\left(\mathrm{cm}^{-1}\right)$ & 1938 (vs) & $2044(w)$ & 1928 (s) \\
\hline \multirow{6}{*}{$\begin{array}{l}\lambda_{\max }(\mathrm{nm}) \\
\quad\left(\varepsilon\left(\mathrm{M}^{-1} \mathrm{~cm}^{-1}\right)\right)^{\mathrm{a}}\end{array}$} & $710(2000)$ & $950(210)$ & $695(610)$ \\
\hline & $486(13000)$ & $617(1950)$ & $648(885)$ \\
\hline & 376 (sh, 2600) & $477(11550)$ & $319(\mathrm{sh}, 8000)$ \\
\hline & $275(41500)$ & $386(\mathrm{sh}, 4250)$ & $263(36300)$ \\
\hline & & 320 (sh, 8250) & \\
\hline & & $270(46000)$ & \\
\hline
\end{tabular}

a Values $\varepsilon$ of the oxidized and reduced forms are low estimates due to minor decomposition during their electrochemical generation.

even higher weight on the cumulenic resonance form $\mathbf{B}$ (see Scheme 1) and hence the lowering of the energy of the CC stretch. In the monooxidized dicationic form the allenylidene ligand bridges a positively charged metal fragment and a positively charged ferrocenium subunit which reduces the dipole transition moment for the symmetric stretch with respect to the monocationic 3. The shift of the HOMO-1/LUMO band in the visible region, on the other hand, displays contrasting behavior to our previous system: here, this band shifts to 477 $\mathrm{nm}$, which is to somewhat higher energies (Fig. 7). This is rather unexpected since the oxidation directly involves the heteroatomic moiety and is therefore expected to lower the LUMO to a higher degree than the HOMO-1. In addition a new, weak and broad feature appears at ca. $880 \mathrm{~nm}$ which requires high concentration in order to be observed. At this point we cannot conclusively say whether this is due to the red shifted HOMO/LUMO transition or to a metal-metal charge transfer band in a mixed valent $\mathrm{Ru}(\mathrm{II})-\mathrm{Fe}(\mathrm{III})$ system although we favor the former interpretation. A new band at $614 \mathrm{~nm}$ (see insert in Fig. 7) is attributed to the ferrocenium chromophor $(642 \mathrm{~nm}$ in trans $\left.\left[\mathrm{Cl}(\mathrm{dppm})_{2} \mathrm{Ru}=\mathrm{C}=\mathrm{C}=\mathrm{C}\left(\mathrm{NMe}_{2}\right) \mathrm{C}_{2} \mathrm{H}_{4} \mathrm{Fc}\right]^{2+}\right)$. The effect of the ruthenium centered oxidation could, however, not be probed for owing to the completely irreversible nature of this process as shown by cyclic voltammetry experiments. The IR and UV-vis properties of 3 in all its accessible redox states are collected in Table 3.

\section{Conclusions}

With trans $-\left[\mathrm{Cl}(\mathrm{dppm}){ }_{2} \mathrm{Ru}=\mathrm{C}=\mathrm{C}=\mathrm{C}(\mathrm{SeFc}) \mathrm{C}_{2} \mathrm{H}_{4} \mathrm{CH}=\right.$ $\left.\mathrm{CH}_{2}\right]^{+}$(3) we present the first selenium substituted allenylidene complex. Its synthesis from $\mathrm{RuCl}_{2}(\mathrm{dppm})_{2}$, butadiyne and allylferrocenylselenide (2) most likely involves the primary butatrienylidene intermediate trans $-\left[\mathrm{Cl}(\mathrm{dppm})_{2} \mathrm{Ru}=\mathrm{C}=\mathrm{C}=\mathrm{C}=\mathrm{CH}_{2}\right]^{+} .3$ is formed by regioselective addition of the selenium nucleophile to $\mathrm{C}_{\gamma}$ followed by Cope-type rearrangement of the allyl vinyl substituted cationic selenium species to the final product as we have observed previously for amine and thioether nucleophiles. The whole reaction may be viewed as a three component cascade reaction with the concomittant formation of a ruthenium-carbon, a carbon-selenium and a carbon-carbon bond and the scission of the selenium-carbon bond to the allyl substituent.

The selenoallenylidene complex 3 features a redoxactive ferrocenylselenyl substituent attached to the extended metallapropadienylidene chromophor giving rise to reversible electrochemistry. The effect of ferrocene oxidation on the spectroscopic properties of the $\mathrm{RuC}_{3} \mathrm{SeFc}$ entity was probed for by in situ IR and UV-vis/NIR spectroelectrochemistry. Upon oxidation, the cumulene type resonance form $[\{R u\}=C=C=$ $\left.\mathrm{C}(\mathrm{SeFc}) \mathrm{R}^{\prime}\right]^{2+}(\mathrm{B})$, which already provides the prominent resonance contributor for the monocation, dominates even more over the alkynyl resonance form $\left[\{\mathrm{Ru}\}-\mathrm{C} \equiv \mathrm{C}-\mathrm{C}(=\mathrm{SeFc}) \mathrm{R}^{\prime}\right]^{2+}$ (A) since the latter involves two adjacent cationic centers. This is shown by the considerable red shift of the CC stretch in the IR region upon oxidation. The reduction involves an orbital delocalized over the allenylidene ligand and, to a lesser degree, the metal center as is seen from the primarily organic character of the resulting radical species and the coupling of the unpaired spin with the methylene group on $\mathrm{C}_{\gamma}$, the selenium and the four equivalent phosphorus nuclei on ruthenium. The reduction also induces an electronic reorganistaion within the unsaturated $\mathrm{C}_{3}$-ligand which is now best described in the alkynyl type resonance form $[\{\mathrm{Ru}\}-\mathrm{C} \equiv \mathrm{C}-$ $\left.\mathrm{C} \cdot(\mathrm{SeFc})\left(\mathrm{C}_{4} \mathrm{H}_{7}\right)\right]$. This follows from the strong blue shift of the CC band upon reduction by more than 100 wavenumbers. 
The ferrocenyselenyl trapping reagent was synthesized from diferrocenyldiselenide 1Se and investigated by cyclic voltammetry. Compound $1 \mathrm{Se}$ was additionally characterized, along with its sulfur analog $1 \mathrm{~S}$ by X-ray structure analysis. Both structures exhibit a close to parallel alignment of all cyclopentadienyl rings of the molecule and a packing motif allowing for extensive $\mathrm{CH} \cdots \pi$ interactions of the 'point-to-face' type. Each Cp-ring acts simultaneously as a $\mathrm{CH}$ donor and a $\pi$ acceptor to different $\mathrm{Cp}$-rings of its immediate neighbors.

\section{Experimental}

\subsection{General reaction conditions}

All reactions were carried out under dry, high purity argon using standard Schlenk techniques. Solvents were dried over appropriate reagents, distilled and stored over molecular sieves under argon before use. Chlorobenzene used in the synthesis of $\mathbf{3}$ was degassed by three freeze-pump-thaw cycles before use.

\subsection{Instrumentation and procedures}

Infrared spectra were obtained on a Perkin Elmer Paragon 1000 PC FT-IR instrument. ' $\mathrm{H}-(250.13$ $\mathrm{MHz}),{ }^{13} \mathrm{C}-(62.90 \mathrm{MHz})$ and ${ }^{31} \mathrm{P}-(101.256 \mathrm{MHz})$ NMR spectra were recorded on a Bruker AC 250 spectrometer at $303 \mathrm{~K}$, and ${ }^{77} \mathrm{Se}(38.168 \mathrm{MHz})$ on a Bruker AM 200 instrument at the same temperature. The spectra were referenced to the residual protonated solvent $\left({ }^{1} \mathrm{H}\right)$ or the solvent signal itself $\left({ }^{13} \mathrm{C}\right)$ or versus $\mathrm{H}_{3} \mathrm{PO}_{4}\left({ }^{31} \mathrm{P}\right)$ or dimethylselenide $\left({ }^{77} \mathrm{Se}\right)$ as external standards. For 3, the assignment of ${ }^{13} \mathrm{C}$-NMR spectra was aided by a DEPT-135 measurement. UV-vis experiments were performed on an Omega 10 spectrometer by Bruins Instruments in HELMA quartz cuvettes whith 1 $\mathrm{cm}$ optical path lengths. The ESR instrumentation consists of a Bruker ESP 3000 spectrometer equipped with a HP frequency counter $5350 \mathrm{~B}$, a Bruker NMR gaussmeter ER $035 \mathrm{M}$ and a continuous flow cryostat ESR 900 from Oxford Instruments for low temperature work. Elemental analyses $(\mathrm{C}, \mathrm{H}, \mathrm{N})$ were performed at in-house facilities. All electrochemical experiments were performed in a self-constructed cylindrical vacuum tight one compartment cell. A spiral shaped Pt wire and a $\mathrm{Ag}$ wire as the counter and reference electrodes are sealed directly into opposite sides of the glass wall while the respective working electrodes (Pt $1 \mathrm{~mm}$, glassy carbon $3 \mathrm{~mm}$, polished with $1 \mu \mathrm{m}$ and $0.25 \mu \mathrm{m}$ diamond paste (Buehler-Wirtz) before each set of experiments) are introduced via a teflon screw cap with a suitable fitting. The cell may be attached to a conventional Schlenk line via two sidearms equipped with teflon screw valves and allows experiments to be performed under an atmosphere of argon with ca. $2.5 \mathrm{ml}$ of analyte solution. The solvents were obtained in the highest available purity from Fluka (Burdick \& Jackson Brand) and freshly distilled before the experiment. $\mathrm{NBu}_{4} \mathrm{PF}_{6}(0.25 \mathrm{mM}$ each) was used as the supporting electrolyte. All potentials are referenced versus ferrocene. For 1 the proximity of the oxidation wave to the ferrocene/ferrocenium couple required indirect calibration by using decamethylferrocene as the internal standard and recalculating the experimental potential scale to the ferrocene standard by the experimental potential of $\mathrm{Cp}_{2}^{*} \mathrm{Fe}^{0 /+}$ with respect to the ferrocene/ferrocenium couple determined in a separate experiment. All electrochemical data were acquired with a computer controlled EG\&G model 273 potentiostat utilizing the EG\&G 250 software package. The OTTLE cell was also self-constructed and comprises a Pt-mesh working and counter electrode and a thin silver wire as a pseudo-reference electrode sandwiched between the $\mathrm{CaF}_{2}$ windows of a conventional liquid IR cell. The working electrode is positioned in the center of the spectrometer beam.

\subsection{Starting materials}

$\mathrm{RuCl}_{2}(\mathrm{dmso})_{4}$ [59], cis $-\mathrm{RuCl}_{2}(\mathrm{dppm})_{2}$ [60] and diferrocenyldiselenide $[29,30]$ were synthesized according to the literature. Butadiyne was prepared from 1,4,dichlorobut-2-yne (Lancaster) by a slight modification of the method by Georgieff [61] and isolated in a dry ice/ethanol bath as a white crystalline solid. Prior to use it was thawed in an ice $/ \mathrm{CaCl}_{2}$ cooling bath and an excess amount transferred via a small pipette. Caution: butadiyne should be handled and stored at dry ice temperatures under rigorous exclusion of oxygen and moisture. tert -Butyllithium, $\mathrm{LiBEt}_{3} \mathrm{H}$, (Aldrich) and Selenium (Chempur) were used as received while allyliodide (Aldrich) was freshly distilled before use.

\subsection{Syntheses}

\subsubsection{Allylferrocenylselenide}

Diferrocenyldiselenide $(0.37 \mathrm{~g}, 0.7 \mathrm{mmol})$ was dissolved in $30 \mathrm{ml}$ of dry deoxygenated THF and cooled to $-78{ }^{\circ} \mathrm{C}$. Within $5 \mathrm{~min} 1.4 \mathrm{ml}$ of a $1 \mathrm{M}$ solution of $\mathrm{LiBEt}_{3} \mathrm{H}$ in THF were added dropwise and then stirred for additional $30 \mathrm{~min}$ at this temperature whereupon the solution turned red. Freshly distilled allyliodide $(127 \mu \mathrm{l})$ was added and the solution warmed to $0{ }^{\circ} \mathrm{C}$ and stirred for additional $60 \mathrm{~min}$. THF was then removed in vacuo and the crude oily product purified by column chromatography over neutral alumina with light petroleum benzene: $\mathrm{CH}_{2} \mathrm{Cl}_{2}$ 1:5 (v:v) as the eluent. From the first orange band the pure product was obtained as an orange viscous oil upon solvent removal 
$(0.41 \mathrm{~g}, 1.377 \mathrm{mmol}, 96.0 \%)$ while the second, brighter orange band contained small amounts of the unreacted diselenide. Anal. Calc. for $\mathrm{C}_{13} \mathrm{H}_{14} \mathrm{FeSe}$ : C, 51.18; $\mathrm{H}$, 4.63. Found: $\mathrm{C}, 51.24, \mathrm{H}, 4.69 \%$. NMR $\left(\mathrm{CDCl}_{3}\right):{ }^{1} \mathrm{H}$ $3.20\left(\mathrm{~d}, 2 \mathrm{H},{ }^{3} J_{\mathrm{HH}}=7.92 \mathrm{~Hz}, \mathrm{CH}_{2}\right), 4.170(\mathrm{~s}, 5 \mathrm{H}, \mathrm{Cp})$, $4.175\left(\mathrm{t}, 2 \mathrm{H},{ }^{3} J_{\mathrm{HH}}=1.75 \mathrm{~Hz}, \mathrm{H}^{3,4}, \mathrm{Cp}_{\text {sub }}\right), 4.29(\mathrm{t}, 2 \mathrm{H}$, $\left.{ }^{3} J_{\mathrm{HH}}=1.75 \mathrm{~Hz}, \mathrm{H}^{1,5}, \mathrm{Cp}_{\mathrm{sub}}\right), 4.85\left(\mathrm{ddt}, 1 \mathrm{H},{ }^{3} J_{\mathrm{HH}, \text { rrans }}=\right.$ $\left.17.2 \mathrm{~Hz},{ }^{4} J_{\mathrm{HH}}=1.3 \mathrm{~Hz},{ }^{2} J_{\mathrm{HH}}=1.1 \mathrm{~Hz},=\mathrm{CH}_{2, \text { trans }}\right), 4.87$ $\left(\mathrm{dd}, 1 \mathrm{H},{ }^{3} J_{\mathrm{HH}, c i s}=9.8 \mathrm{~Hz},{ }^{2} J_{\mathrm{HH}}=1.1 \mathrm{~Hz},=\mathrm{CH}_{2, c i s}\right)$, $5.88(\mathrm{~m}, 1 \mathrm{H},=\mathrm{CH}) .{ }^{13} \mathrm{C}\left(\mathrm{CDCl}_{3}\right) 32.09\left(\mathrm{CH}_{2}, J_{\mathrm{CSe}}=\right.$ $56.9 \mathrm{~Hz}), 69.14(\mathrm{Cp}), 69.56\left(\mathrm{C}^{3,4}\right), 70.20\left(\mathrm{C}^{1}\right), 75.24$ $\left(\mathrm{C}^{2,5}\right) 117.54\left(=\mathrm{CH}_{2}\right), 135.07(=\mathrm{CH})$.

\subsection{2. trans $-\left[C l(d p p m)_{2} R u=C=C=C(S e F c) C_{2} H_{4} \mathrm{CH}=\right.$ $\left.\mathrm{CH}_{2}\right]^{+}$(3)}

$\mathrm{RuCl}_{2}(\mathrm{dppm})_{2}(0.175 \mathrm{~g}, 0.186 \mathrm{mmol}), \mathrm{NaSbF}_{6}(0.192$ $\mathrm{g}, 0.74 \mathrm{mmol}$ ) and excess butadiyne were dissolved/suspended in $\mathrm{CH}_{2} \mathrm{Cl}_{2}$ and stirred at room temperature (r.t.). After $30 \mathrm{~min}$ the resulting solution turned intense green and $2(0.142 \mathrm{~g}, 0.465 \mathrm{mmol})$, dissolved in $5 \mathrm{ml}$ $\mathrm{CH}_{2} \mathrm{Cl}_{2}$, was added. It was stirred for 3 days at r.t. under occasional IR monitoring until the intensity and shape of the new absortion band at $1938 \mathrm{~cm}^{-1}$ remained constant. During this time the solution color changed gradually from dark green to orange brown. Excess $\mathrm{NaSbF}_{6}$ and $\mathrm{NaCl}$ were filtered off by a paper tipped cannula and the solvent was removed in vacuo. The solid residue was washed four times with $15 \mathrm{ml}$ portions of $\mathrm{Et}_{2} \mathrm{O}$, then dried and reprecipitated two times by slowly adding its concentrated $\mathrm{CH}_{2} \mathrm{Cl}_{2}$ solution to $20 \mathrm{ml}$ of rapidly stirred hexanes. The dark brown, powdery solid was then dried in vacuo to yield $0.188 \mathrm{~g}$ of $3(0.126 \mathrm{mmol}, 67.6 \%)$. Anal. Calc. for $\mathrm{C}_{67} \mathrm{H}_{60} \mathrm{~F}_{6} \mathrm{FeClP}{ }_{4} \mathrm{RuSbSe} \cdot 0.5 \mathrm{CH}_{2} \mathrm{Cl}_{2}: \mathrm{C}, 52.69 ; \mathrm{H}, 4.00$. Found: C, 52.94, H, 3.94\%. NMR, ${ }^{1} \mathrm{H}\left(\mathrm{CD}_{2} \mathrm{Cl}_{2}\right): 1.39$ (m, $4 \mathrm{H}, \mathrm{CH}_{2}$ ), 4.25 (s,br. $\left.2 \mathrm{H}, \mathrm{H}^{3,4}, \mathrm{Cp}_{\text {sub }}\right), 4.27$ (s, $5 \mathrm{H}$, $\mathrm{Cp}), 4.47$ (s, br. $\left.2 \mathrm{H}, \mathrm{H}^{2,5}, \mathrm{Cp}_{\text {sub }}\right), 4.46(\mathrm{~d}$, br., $1 \mathrm{H}$, $\left.=\mathrm{CH}_{2, \text { rrans }},{ }^{3} J_{\mathrm{HH}}=17.2 \mathrm{~Hz}\right), 4.84\left(\mathrm{~d}\right.$, br. $1 \mathrm{H},=\mathrm{CH}_{2, \text { cis }}$, $\left.{ }^{3} J_{\mathrm{HH}}=10.5 \mathrm{~Hz}\right), 5.07 \mathrm{ppm}\left(\mathrm{m}\right.$, br. $2 \mathrm{H}, \mathrm{CH}_{2}(\mathrm{dppm})$ ), 5.22 (m, br. $\left.3 \mathrm{H}, \mathrm{CH}_{2}(\mathrm{dppm}),=\mathrm{CH}\right), 5.32\left(\mathrm{CH}_{2} \mathrm{Cl}_{2}\right)$, 7.00-7.65 (m, 40H, arene(dppm)). ${ }^{13} \mathrm{C}\left(\mathrm{CD}_{2} \mathrm{Cl}_{2}\right): 32.06$, $45.59\left(\mathrm{CH}_{2}\right), 47.55$ (quint, $J_{\mathrm{PC}}=11.6 \mathrm{~Hz}, \mathrm{CH}_{2}(\mathrm{dppm})$ ), $69.36\left(\mathrm{C}^{1}, \mathrm{Cp}_{\text {sub }}\right), 70.08(\mathrm{Cp}), 72.13\left(\mathrm{C}^{3,4}, \mathrm{Cp}_{\text {sub }}\right), 75.21$ $\left(\mathrm{C}^{2,5}, \mathrm{Cp}_{\mathrm{sub}}\right), 115.89\left(=\mathrm{CH}_{2}\right), 128.61\left(J_{\mathrm{PC}}=2.65 \mathrm{~Hz}\right)$ and $129.67\left(J_{\mathrm{PC}}=2.65 \mathrm{~Hz}, \mathrm{C}^{\text {meta }}(\mathrm{dppm})\right), 131.02\left(J_{\mathrm{PC}}=\right.$ $\left.12.5 \mathrm{~Hz}, \mathrm{C}^{\text {ipso }}(\mathrm{dppm})\right), 131.17,131.33\left(\mathrm{C}^{\text {para }}(\mathrm{dppm})\right)$, $132.63\left(J_{\mathrm{PC}}=11.8 \mathrm{~Hz}, \mathrm{C}^{i p s o}(\mathrm{dppm})\right), 132.89\left(J_{\mathrm{PC}}=3.15\right.$ $\mathrm{Hz})$ and $139.63 \mathrm{ppm}\left(J_{\mathrm{PC}}=3.15 \mathrm{~Hz}, \mathrm{C}^{\text {ortho }}(\mathrm{dppm})\right)$, $135.84(\mathrm{CH}), 180.63\left({ }^{4} J_{\mathrm{PC}}=1.83 \mathrm{~Hz}, \mathrm{C}_{y}\right), 180.82$ $\left({ }^{3} J_{\mathrm{PC}}=2.33 \mathrm{~Hz}, \mathrm{C}_{\beta}\right), 303.19\left({ }^{2} J_{\mathrm{PC}}=14.1 \mathrm{~Hz}, \mathrm{C}_{\alpha}\right) \cdot{ }^{31} \mathrm{P}$ $\left(\mathrm{CD}_{2} \mathrm{Cl}_{2}\right):-12.66$ (s). IR $(\mathrm{KBr})$ v $\left(\mathrm{cm}^{-1}\right)$ : CC 1932 (vs), dppm: 1582 (w), 1572(w), 1483(m), 1435(s), 1096(s), 1025(m), 999(m),736 (s), 727(s), 693(vs), 520(s), 504(vs), Fc: 304 (m), SbF- 657(vs), 289(s).

\section{Supplementary material}

Crystallographic data for the structural analysis have been deposited with the Cambridge Crystallographic Data Centre, CCDC Nos. 154794 (1Se) and 154795 (1S). Copies of this information may be obtained free of charge from The Director, CCDC, 12 Union Road, Cambridge CB2 1EZ, UK (fax: + 44-1233-336-033; e-mail: deposit@ccdc.cam.ac.uk or www: http:// www.ccdc.cam.ac.uk).

\section{Acknowledgements}

This work was financially supported by the VWStiftung within their programme on 'Intra- and Intermolecular Electron Transfer'. We wish to thank Dr Klaus Hübler for his aid in the structure refinement, and cand. chem. Raoul Klingmann for his work during an advanced laboratory course. Johnsson \& Matthey Inc. is acknowledged for the generous loan of hydrated $\mathrm{RuCl}_{3}$.

\section{References}

[1] F. Stein, M. Duetsch, E. Pohl, R. Herbst-Irmer, A.d. Meijere, Organometallics 12 (1993) 2556.

[2] M. Duetsch, F. Stein, R. Lackmann, E. Pohl, R. Herbst-Irmer, A.d. Meijere, Chem. Ber. 125 (1992) 2051.

[3] R. Aumann, B. Jasper, R. Fröhlich, Organometallics 14 (1995) 3173.

[4] E.-O. Fischer, H.J. Kalder, A. Frank, F.H. Köhler, G. Huttner, Angew. Chem. 88 (1976) 683.

[5] J.R. Lomprey, J.P. Selegue, Organometallics 12 (1993) 616.

[6] M.I. Bruce, P. Hinterding, P.J. Low, B.W. Skelton, A.H. White, J. Chem. Soc. Dalton Trans. (1998) 467.

[7] M.I. Bruce, P. Hinterding, P.J. Low, B.W. Skelton, A.H. White, J. Chem. Soc. Chem. Commun. (1996) 1009.

[8] R.F. Winter, Chem. Commun. (1998) 2209.

[9] G. Roth, H. Fischer, Organometallics 15 (1996) 1139.

[10] A. Romero, D. Peron, P.H. Dixneuf, J. Chem. Soc. Chem. Commun. (1990) 1410.

[11] A. Wolinska, D. Touchard, P.H. Dixneuf, J. Organomet. Chem. 420 (1991) 217.

[12] D. Touchard, P. Haquette, A. Daridor, L. Toupet, P.H. Dixneuf, J. Am. Chem. Soc. 116 (1994) 11157.

[13] D. Touchard, N. Pirio, L. Toupet, M. Fettouhi, L. Ouahab, P.H. Dixneuf, Organometallics 14 (1995) 5263.

[14] R.F. Winter, Organometallics 16 (1997) 4248.

[15] R.F. Winter, Eur. J. Inorg. Chem. (1999) 2121.

[16] R.F. Winter, K.-W. Klinkhammer, S. Záliš, Organometallics 20 (2001) 1317

[17] N.L. Narvor, L. Toupet, C. Lapinte, J. Am. Chem. Soc. 117 (1995) 7129

[18] F. Coat, M.-A. Guillevic, L. Toupet, F. Paul, C. Lapinte, Organometallics 16 (1997) 5988.

[19] M. Guillemot, L. Toupet, C. Lapinte, Organometallics 17 (1998) 1928.

[20] F. Coat, C. Lapinte, Organometallics 15 (1996) 477.

[21] M. Brady, W. Weng, Y. Zhou, J.W. Seyler, A.J. Amoroso, A.M. Arif, M. Böhme, G. Frenking, J.A. Gladysz, J. Am. Chem. Soc. 119 (1997) 775. 
[22] S. Kheradmandan, K. Heinze, H.W. Schmalle, H. Berke, Angew. Chem. 111 (1999) 2412

[23] R. Dembinski, T. Bartik, B. Bartik, M. Jaeger, J.A. Gladysz, J. Am. Chem. Soc. 122 (2000) 810.

[24] M.I. Bruce, L.I. Denisovich, P.J. Low, S.M. Peregudova, N.A. Ustynyuk, Mendeleev Commun. (1996) 200.

[25] M.I. Bruce, P.J. Low, K. Costuas, J.-F. Halet, S.P. Best, G.A. Heath, J. Am. Chem. Soc. 122 (2000) 1949.

[26] T. Ren, G. Zou, J.C. Alvarez, Chem. Commun. (2000) 1197.

[27] B.E. Woodworth, J.L. Templeton, J. Am. Chem. Soc. 118 (1996) 7418.

[28] (a) R. Dembinski, S. Szafert, P. Haquette, T. Lis, J.A. Gladysz, Organometallics 18 (1999) 5438;

(b) S. Guesmi, D. Touchard, P.H. Dixneuf, Chem. Commun. (1996) 2773.

[29] M. Herberhold, P. Leitner, J. Organomet. Chem. 336 (1987) 153.

[30] M. Herberhold, O. Nuyken, T. Pöhlmann, J. Organomet. Chem. 405 (1991) 217

[31] Y. Nishibayashi, J.D. Singh, S.-I. Fukuzawa, S. Uemura, J. Org. Chem. 60 (1995) 4114.

[32] Y. Kobayashi, K. Segawa, J.D. Singh, S.-i. Fukuzawa, K. Ohe, S. Uemura, Organometallics 15 (1996) 370.

[33] H. Gornitza, S. Besser, R. Herbst-Irmer, U. Kilimann, F.T. Edelmann, J. Organomet. Chem. 437 (1992) 299.

[34] G. Mugesh, A. Panda, H.B. Singh, N.S. Punekar, R.J. Butcher, Chem. Commun. (1998) 2227

[35] M. Herberhold, H.-D. Brendel, U. Thewalt, Angew. Chem. 103 (1991) 1664

[36] C. Janiak, J. Chem. Soc. Dalton Trans. (2000) 3885.

[37] E.G. Cox, D.W. Cruickshank, J.A.S. Smith, Proc. R. Soc. Lond. Ser. A 247 (1958) 1.

[38] G.E. Beacon, N.A. Curry, S.A. Wilson, Proc. R. Soc. Lond. Ser. A 279 (1964) 98.

[39] R.L. Jaffe, G.D. Smith, J. Chem. Phys. 105 (1996) 2780.
[40] D.E. Williams, Acta Crystallogr. Sect. A 36 (1980) 715.

[41] D.E. Williams, Y. Xiao, Acta Crystallogr. Sect. A 49 (1993) 1.

[42] Y. Umezawa, S. Tsuboyama, K. Honda, J. Uzawa, M. Nishio, Bull. Chem. Soc. Jpn. 71 (1998) 1207.

[43] C. Janiak, S. Temizdemir, S. Dechert, W. Deck, F. Girgsdies, J. Heinze, M.J. Kolm, T.G. Scharmann, O.M. Zipffel, Eur. J. Inorg. Chem. (2000) 1229.

[44] H.-C. Weiss, D. Bläser, R. Boese, B.M. Doughan, M.M. Haley, Chem. Commun. (1997) 1703.

[45] T. Steiner, M. Tamm, B. Lutz, J.v.d. Maas, Chem. Commun. (1996) 1127

[46] E.O. Fischer, Pure Appl. Chem. 24 (1970) 407.

[47] E.O. Fischer, G. Kreis, F.R. Kreißl, C.G. Kreiter, J. Müller, Chem. Ber. 106 (1973) 3910.

[48] A.F. Hill, A.G. Hulkes, A.J.P. White, D.J. Williams, Organometallics 19 (2000) 371 .

[49] R.F. Winter, F.M. Hornung, Organometallics 18 (1999) 4005.

[50] G.B. Bennett, Synthesis (1977) 589.

[51] R.P. Lutz, Chem. Rev. 84 (1984) 205.

[52] M.I. Bruce, Chem. Rev. 98 (1998) 2797.

[53] E.O. Fischer, M. Leupold, C.G. Kreiter, J. Müller, Chem. Ber. 105 (1972) 150

[54] P. Shu, K. Bechgaard, D.O. Cowan, J. Org. Chem. 41 (1976) 1849.

[55] R.S. Nicholson, I. Shain, Anal. Chem. 36 (1964) 706.

[56] K.J. Harlow, A.F. Hill, J.D.E.T. Wilton-Ely, J. Chem. Soc. Dalton Trans. (1999) 285.

[57] R. Prins, A.R. Korswagen, J. Organomet. Chem. 25 (1970) C74.

[58] D.E.M. Duggan, D.N. Hendrickson, Inorg. Chem. 14 (1975) 955.

[59] I.P. Evans, A. Spencer, G. Wilkinson, J. Chem. Soc. (1973) 204.

[60] B. Chaudret, G. Commenges, R. Poilblanc, J. Chem. Soc. Dalton Trans. (1984) 1635.

[61] K.K. Georgieff, Y. Richard, Can. J. Chem. 36 (1958) 1280. 